\title{
Screening of Less known Two Food Plants for Comparison of Nutrient Contents: Iranian and Indian Vegetables
}

\author{
Ali Aberoumand \\ Department of Fisheries, Behbahan Khatemolanbia Technology University, Behbahan, \\ Khuzestan Province, Iran \\ Corresponding author: Ali Aberoumand, $\mathrm{PhD}$, Department of Fisheries, Behbahan \\ Khatemolanbia Technology University, Behbahan, Khuzestan Province, Iran
}

Submission date: September 14, 2011; Acceptance date: Octoberr 16, 2011; Publication date: October 22, 2011

\begin{abstract}
$\underline{\text { Abstract }}$
Background: Greater consumption of fruits and vegetables is associated with reduced risk of cardiovascular disease, stroke, and cancers. The most important nutrients present in plants are carbohydrates, such as the starch and free sugars, oils, proteins, minerals, ascorbic acid, and the antioxidant phenols. Plants are an essential component of the universe. Human beings have used those as medicine from the very beginning of time.
\end{abstract}

Methods: The proximate composition and mineral constituents of Asparagus officinalis stem and Momordica dioica fruit were evaluated in order to scientific standard methods of Association for Official and Analytical Chemists (AOAC).

Results: The stem contained ashes: $10.70 \%$ crude protein: $32.69 \%$, crude lipid: $3.44 \%$, crude fiber: $18.50 \%$, and carbohydrates: $34.67 \%$. Stem also have high energy value $(384.27 \mathrm{kcal} / 100 \mathrm{~g})$ dry weight. Mineral ranges (mg/100g dry weight, DW) were: K (10.94), Na (1.84), Ca (0.67), Fe (0.19), and $\mathrm{Zn}$ (2.60). The fruits contained ashes: $9.1 \%$, crude protein: $5.44 \%$, crude lipid: $3.25 \%$, crude fiber: $22.9 \%$, and carbohydrates: $59.31 \%$. The fruits also have high energy value $(288.25 \mathrm{kcal} / 100 \mathrm{~g})$ dry weight. Mineral ranges $(\mathrm{mg} / 100 \mathrm{~g}$ dry weight, DW) were: K (4.63), Na (1.62), Ca (7.37), Fe (5.04), and Zn (3.83).

Conclusion: Comparing proximate and minerals contents of the stem and the fruit, the results indicated that Asparagus officinalis stem could be a good supplement for some nutrients such as protein, lipid, potassium and zinc, fibre and carbohydrates while Momordica dioica fruit was good source of lipid, crude fiber, carbohydrates, iron and zinc. 
Keywords: Asparagus officinalis stem; Momordica dioica; Micronutrients; Proximate and Mineral composition.

\section{BACKGROUND:}

In developing nations, numerous types of edible wild plants are exploited as sources of food hence provide an adequate level of nutrition to the inhabitants. Recent studies on agro pastoral societies in Africa indicate that these, plant resources play a significant role in nutrition; food security and income generation [5].

Furthermore, FAO report, at least one billion people are thought to use wild foods in their diet [6]. In Ghana alone, the leaves of over 300 species of wild plants and fruits are consumed. In Swaziland, wild plants provide a greater share of the diet than domesticated cultivars. In India, Malaysia and Thailand, about 150 wild plants species have been identified as sources of emergency food [8]. Similarly, in South Africa about 1400 edible plant species are used, In Sahel region of Africa, over 200 wild foods were identified to be used by the rural communities [17]. In most of these reports, it was emphasized that nutritionally, these unconventional plants foods could be comparable to or even sometimes superior to the introduced cultivars [7]. It is, therefore, worthwhile to note that the incorporation of edible wild and semi-cultivated plant resources could be beneficial to nutritionally marginal populations or to certain vulnerable groups within populations, especially in developing countries where poverty and climatic changes are causing havoc to the rural populace. In this context, analyses were carried out to evaluate the nutritional content of Asparagus officinalis stem and Momordica dioica fruit with hope that it would be incorporated into the food basket of the country [8-11]. The aim of analysis of nutrients in the plant foods is preliminary assessment of nutritional value of the plant-based diet.

\section{MATERIALS AND METHODS:}

\section{Plant material}

Asparagus officinalis stem and Momordica dioica fruits used as experimental material were collected from farm and Agricultural lands (garden) in around Behbahan, South Iran, in October 2007. Extent of production/availability of the plants was in areas of Maharashtra state in India and southern Iran, Behbahan. The collected plant material was placed in a polyethylene bag to prevent loss of moisture during transportation to the laboratory.

\section{Preparation of the plant materials for chemical analyses}

Asparagus officinalis stem and Momordica dioica fruits were washed with distilled water and dried at room temperature to remove residual moisture, then placed in paper envelope and ovendried at $55^{\circ} \mathrm{C}$ for 24 hours ${ }^{2,3}$. The dried stem were ground into powder using pestle and mortar, and sieved through 20-mesh sieve. The root tubers powder was used for the nutrients analyzes.

\section{Plant foods chemical analysis}


The methods recommended by the Association of Official Analytical Chemists were used to determine ash (\#942.05), crude lipid (\#920.39), crude fibre (\#962.09) and nitrogen content (\#984.13)[4].

\section{Determination of crude lipid and crude fibre Content}

Two grams of dried root tubers or fruits were weighed in a porous thimble of a Soxhlet apparatus, with its mouthed cotton wool plugged. The thimble was placed in an extraction chamber which was suspended above a pre-weighed receiving flask containing petroleum ether (b.p. $40-60^{\circ} \mathrm{C}$ ). The flask was heated on a heating mantle for eight hours to extract the crude lipid. After the extraction, the thimble was removed from the Soxhlet apparatus and the solvent distilled off. The flask containing the crude lipid was heated in the oven at $100^{\circ} \mathrm{C}$ for 30 minutes to evaporate the solvent, then cooled in a dessicator, and reweighed. The difference in weight was expressed as percentage crude lipid content.

Crude fiber was estimated by acid-base digestion with $1.25 \% \quad \mathrm{H}_{2} \mathrm{SO}_{4}$ (prepared by diluting $7.2 \mathrm{ml}$ of $94 \%$ conc. acid of specific gravity $1.835 \mathrm{~g} \mathrm{ml}-1$ per $1000 \mathrm{ml}$ distilled water) and $1.25 \% \mathrm{NaOH}(12.5 \mathrm{~g}$ per $1000 \mathrm{ml}$ distilled water) solutions. The residue after crude lipid extraction was put into a $600 \mathrm{ml}$ beaker and $200 \mathrm{ml}$ of boiling $1.25 \% \mathrm{H}_{2} \mathrm{SO}_{4}$ added. The contents were boiled for 30 minutes, cooled, filtered through a filter paper and the residue washed three times with $50 \mathrm{ml}$ aliquots of boiling water. The washed residue was returned to the original beaker and further digested by boiling in $200 \mathrm{ml}$ of $1.25 \% \mathrm{NaOH}$ for 30 minutes. The digest was filtered to obtain the residue. This was washed three times with $50 \mathrm{ml}$ aliquots of boiling water and finally with $25 \mathrm{ml}$ ethanol.

The washed residue was dried in an oven at $130^{\circ} \mathrm{C}$ to constant weight and cooled in a dessicator. The residue was scraped into a pre-weighed porcelain crucible, weighed, ashed at $550^{\circ} \mathrm{C}$ for two hours, cooled in a dessicator and reweighed. Crude fibre content was expressed as percentage loss in weight on ignition, $[4,14]$.

\section{Determination of nitrogen content and estimation of crude protein}

Macro-Kjeldahl method was used to determine the nitrogen content of the stem $2 \mathrm{~g}$ of dried plants were digested in a $100 \mathrm{ml} \mathrm{Kjeldahl} \mathrm{digestion} \mathrm{flask} \mathrm{by} \mathrm{boiling} \mathrm{with} 10 \mathrm{ml}$ of concentrated tetraoxosulphate (VI) acid and a Kjeldahl digestion tablet (a catalyst) until the mixture was clear. The digest was filtered into a $100 \mathrm{ml}$ volumetric flask and the solution made up to $100 \mathrm{ml}$ with distilled water. Ammonia in the digest was steam distilled from $10 \mathrm{ml}$ of the digest to which had been added $20 \mathrm{ml}$ of $45 \%$ sodium hydroxide solution. The ammonia liberated was collected in 50 $\mathrm{ml}$ of $20 \%$ boric acid solution containing a mixed indicator. Ammonia was estimated by titrating with standard $0.01 \mathrm{~mol} \mathrm{L-1} \mathrm{HCl}$ solution. Blank determination was carried out in a similar manner. Crude protein was estimated by multiplying the value obtained for percentage nitrogen content by a factor of 6.25 [4].

\section{Estimation of carbohydrates and energy values}

Available carbohydrate was estimated by difference, by subtracting the total sum of percent crude protein, crude lipid, crude fibre and ash from $100 \%$ DW of the plant the plant calorific 
value (in $\mathrm{kJ}$ ) was estimated by multiplying the percentages of crude protein, crude lipid and carbohydrate by the factors $16.7,37.7$ and 16.7 respectively [4].

\section{Mineral analysis}

The mineral elements $\mathrm{Na}, \mathrm{K}, \mathrm{Ca}, \mathrm{Fe}$, and $\mathrm{Zn}$ were determined on $0.3 \mathrm{~g}$ plant powder by the methods of Funtua. using Energy Dispersive X-ray Fluorescence (EDXRF) transmission emission spectrometer carrying an annular $25 \mathrm{mCi} 109 \mathrm{Cd}$ isotopic excitation source that emits Ag-K X-ray $(22.1 \mathrm{keV})$ and a Mo X-ray tube $(50 \mathrm{KV}, 5 \mathrm{~mA})$ with thick foil of pure Mo used as target material for absorption correction. The system had a Canberra Si (Li) detector with a resolution of $170 \mathrm{eV}$ at $5.9 \mathrm{keV}$ line and was coupled to a computer controlled ADCCard (Trump $8 \mathrm{~K})$.

Measurements were carried out in duplicate. $\mathrm{Na}$ was analyzed after wet digestion of one gramme of the stem powder with nitric/perchloric/sulphuric acid (9:2:1 v/v/v) mixture. Sodium was analyzed with a Corning 400 flame photometer [4].

\section{RESULTS AND DISCUSSION:}

\section{Proximate analysis}

The results of proximate composition of Asparagus officinalis stem and Momordica dioica fruits are shown in Tables 1 and 2.

Table 1. Proximate composition of Asparagus officinalis stem

\begin{tabular}{|l|l|}
\hline Parameters & Concentration $(\% \mathbf{D W}) *$ \\
\hline Ash & $10.70 \pm 0.80$ \\
\hline Crude protein & $32.69 \pm 0.27$ \\
\hline Crude lipid & $3.44 \pm 0.50$ \\
\hline Crude fibre & $18.55 \pm 0.35$ \\
\hline Carbohydrates & $34.69 \pm 0.68$ \\
\hline Calorific value $(\mathrm{kcal} / 100 \mathrm{~g})$ & $384.27 .52 \pm 5.31$ \\
\hline
\end{tabular}

* The data are mean values $\underline{ \pm}$ deviation $(\mathrm{SD})$ of three replicates.

* Values expressed as \% dried weight.

The ash content, which is an index of mineral contents, for Asparagus officinalis stem was more than to the values reported for other edible leaves such as Momordica balsamina leaves where as for Momordica dioica fruits the value of $6.7 \%$ DW was less than the reported values [3,5,8]. It is apparent that Asparagus officinalis stem are a good source of Potassium. The crude protein content of both edible plants was more than what is reported for some lesser known wild leafy vegetables such as Momordica balsamina (11.29 $\pm 0.07 \%)$, Moringa oleifera (20.72\%), Lesianthera africana leaves $(13.10-14.90 \%)$ and Leptadenia hastate $(19.10 \%)$ [15,16]. Plant food that provide more than $12 \%$ of their calorific value from protein are a good source of protein. In that context, Asparagus officinalis stem and Momordica dioica fruits are good sources 
of protein. The crude lipid contents of both plant foods were less than the range $(8.3-27.0 \%$ DW) reported for some vegetables consumed in Nigeria and Republic of Nigeria [13,14].

Table 2. Proximate composition of Momordica dioica fruit

\begin{tabular}{|l|l|}
\hline Parameters & Contents \\
\hline Ash & $6.7 \pm 5.17$ \\
\hline Crude protein & $19.38 \pm 0.27$ \\
\hline Crude lipid & $4.7 \pm 0.50$ \\
\hline Crude fibre & $21.3 \pm 0.35$ \\
\hline Carbohydrates & $47.92 \pm 0.68$ \\
\hline Calorific value(kcal/100g) & $311.5 \pm 5.31$ \\
\hline
\end{tabular}

* The data are mean values $\underline{ \pm}$ deviation $(\mathrm{SD})$ of three replicates.

* Values expressed as \% dried weight.

The estimated carbohydrate contents in Asparagus officinalis stem and in Momordica dioica fruits were stand to be higher than that for Senna obtusfolia leaves (20\%) and Amaranthus incurvatus leaves (23.7\%). On the other hand, Asparagus officinalis stem and M. dioica fruits contain comparable amount of carbohydrate for Momordica balsamina $(39.05 \pm 2.01 \%)$. The crude fibre content in both plant foods were more than the reported values $(8.50-20.90 \%)$ for some Nigeria vegetables, [12]. One discussed drawback to the use of vegetables in human nutrition is their high non soluble fibre content, which may cause intestinal irritation and a decrease of nutrient bioavailability. The fibre RDA values for children, adults, pregnant and breast-feeding mothers are $19-25 \%, 21-38 \%, 28 \%$ and $29 \%$ respectively. The reason for the variation in nutrient content compared to available data by AOAC was due to species variation.

\section{Mineral content}

Table 3 and 4 show the results of the mineral concentrations of Asparagus officinalis stem and Momordica dioica fruits. Nutritional significance of elements is compared with the standard recommended dietary allowance. When compared with standard values as showed in Table 3 and 4, Asparagus officinalis stem and $M$. dioica fruits less than adequate level of $\mathrm{K}, \mathrm{Fe}, \mathrm{Zn}, \mathrm{Ca}$, and $\mathrm{Na}$, but the plant stem could be good sources of $\mathrm{K}$.

Table 3. Mineral composition of Asparagus officinalis stem

\begin{tabular}{|l|l|l|l|l|l|}
\hline \multicolumn{7}{|c|}{ Recommended Dietary Allowances(mg/day) } \\
\hline Mineral & $\begin{array}{l}\text { Available } \\
\text { Quantity in } \\
\text { mg/100g } \\
\text { DW* }\end{array}$ & $\begin{array}{l}\text { Children } \\
\text { 7-10 Years }\end{array}$ & Adult male & Adult female & $\begin{array}{l}\text { Pregnant and } \\
\text { Lactating } \\
\text { mother }\end{array}$ \\
\hline
\end{tabular}




\begin{tabular}{|l|l|l|l|l|l|}
\hline Potassium & $10.94 \pm 0.02$ & 800 & 800 & 800 & 1200 \\
\hline Calcium & $0.67 \pm 0.15$ & 1600 & 2000 & 2000 & 2000 \\
\hline Sodium & $1.84 \pm 0.08$ & 400 & 500 & 400 & 500 \\
\hline Iran & $0.19 \pm 0.01$ & 10 & 10 & 15 & 13 \\
\hline Zinc & $2.60 \pm 0.07$ & 10 & 15 & 12 & 19 \\
\hline
\end{tabular}

* The data are mean values \pm deviation(SD) of three replicates.

Table 4. Mineral composition of Momordica dioica fruit

\begin{tabular}{|c|c|c|c|c|c|}
\hline \multicolumn{6}{|c|}{ Recommended Dietary Allowances (mg/day) } \\
\hline Minerals & $\begin{array}{l}\text { Available } \\
\text { quantity in } \\
\mathrm{mg} / 100 \mathrm{gD} *\end{array}$ & $\begin{array}{l}\text { Children } \\
\text { 7-10years }\end{array}$ & $\begin{array}{l}\text { Adult } \\
\text { Male }\end{array}$ & $\begin{array}{l}\text { Adult } \\
\text { female }\end{array}$ & $\begin{array}{l}\text { Pregnant and } \\
\text { lactating Mothers }\end{array}$ \\
\hline Calcium & $0.46 \pm 0.02$ & 800 & 800 & 800 & 1200 \\
\hline Potassium & $8.25 \pm 0.15$ & 1600 & 2000 & 2000 & 2000 \\
\hline Sodium & $1.51 \pm 0.08$ & 400 & 500 & 400 & 500 \\
\hline Iron & $0.14 \pm 0.01$ & 10 & 10 & 15 & 13 \\
\hline Zinc & $1.34 \pm 0.07$ & 10 & 15 & 12 & 19 \\
\hline
\end{tabular}

* The data are mean values \pm deviation $(\mathrm{SD})$ of three replicates.

\section{CONCLUDING REMARKS:}

The results of the nutrient content analysis shows that Asparagus officinalis stem could be a good supplement for some nutrients such as protein, lipid, potassium and Zinc, fibre and carbohydrates while Momordica dioica fruit was good source of lipid, crude fiber, carbohydrates, Fe and Zinc.

The results suggests that the plant fruits if consumed in sufficient amount could contribute greatly towards meeting human nutritional requirement for normal growth against malnutrition and adequate protection against diseases arising from infectious microorganisms . From the result, Asparagus officinalis stem and Momordica dioica fruits are recommend for regular useage as nutritionally rich sources for protein and certain micronutrients, considering the amount and diversity of nutrients it contains. Chemical analysis alone however, should not be 
the exclusive criteria for judging the nutritional significance of plant parts for human consumption as food. Thus, it becomes necessary to consider order aspects such as presence of any antinutritional / toxicological factors and biological evaluation of nutrient content, [1].

Abbreviations: AOAC: Association of Official Analytical Chemists, FAO: Food and Agricultural Organization, RDA: recommended dietary allowances; DW: dried weight.

Acknowledgements: The authors are grateful to Head Department of Food Science Technology of Ramin Agricultural University of Iran for providing necessary laboratory facilities and for encouragement.

\section{REFERENCES:}

1. Aberoumand A, Deokule SS, Comparison of Phenolic compounds of some edible plants of Iran and India, Pakistan J of Nutr. 2008.7 (4): 582-585.

2. Abuye C, Urga K, Knapp H, Selmar D, Omwega A, Imungi J, Winterhalter P. A compositional study of moringa stenopetala leaves. East African Med J 2003.80(5): 24752.

3. Aletor V, Adeogun O. Chemical analysis of the fruit of Vitex doniana (Verbenaceae). Food Chem 1995. 53: 375-379.

4. AOAC Official methods of analysis, 14th edition, Association of Official Analytical Chemists, Washington DC. Arlington, Virginia, USA. 1990.

5. Asibey-Berko E, Tayie F. The antibacterial properties of some plants found in Hawaii, Ghana J Sci 1999. 39: 91-92.

6. Burlingame B. Comparison of total lipids, fatty acids, sugars and nonvolatile organic acids in nuts from Castanea species. J of Food Comp and Anal 2000.13: 99-100.

7. Edmonds J, Chweya J. 1995 Black nightshades, Solanum nigrum L. and related species. Promoting the conservation and use of underutilized and neglected crops. Taylor \& Francis, London.

8. Faruq U, Sani A, Hassan L. Composition and distribution of deadly nightshade. Niger Journal of Basic Appl Sci 2002. 11: 157-164.

9. Hazell T.1985; Minerals in foods: dietary sources, chemical forms, interactions, bioavailability. World Rev Nutr Diet. 46:1-123.

10. Funtua I, Trace J. Quantitative variability in Pisum seed globulins: its assessment and significance. Plant Foods for Human Nutr 1999, 17: 293-297.

11. Ifon E, Bassir O. Determination of carbohydrates in foods. II-unavailable carbohydrates. Food Chem 1980, 5: 231-235.

12. Isong EU, Idiong UI. 1997; Comparative studies on the nutritional and toxic composition of three varieties of Lesianthera africana. Source Department of Biochemistry, University of Uyo, Nigeria. Plant Foods Hum Nutr. 51(1):79-84.

13. Mottram DS, Wedzicha BL, Dodson AT. 2002 Acrylamide is formed in the Maillard reaction. Source School of Food Biosciences, The University of Reading, Whiteknights, Reading RG6 6AP, UK. Nature. 3;419:448-9. 
14. Nesamvuni C, Steyn N, Potgieter M. nutrients analysis of selected western African foods, South African J Sci 2001. 97: 51-54.

15. Pearson D. Nutrient and chemical composition of 13 wild plant foods of Niger. Ghana J. Sci 1999. 39:.91- 92.

16. Plessi M, Bertelli D, Phonzani A, Simonetti M, Neri A, Damiani P. Role of indigenous leafy vegetables in combating hunger and malnutrition, J of Food Comp and Anal 1999. 12: 91-96.

17. Sena LP, Vanderjagt DJ, Rivera C, Tsin AT, Muhamadu I, Mahamadou O, Millson M, Pastuszyn A, Glew RH. 1998; Analysis of nutritional components of eight famine foods of the Republic of Niger. Source,Department of Biochemistry and Molecular Biology, University of New Mexico School of Medicine, Albuquerque 87131-5221, USA Plant Foods Hum Nutr. 52(1):17-30. 